\title{
Corporate Social Responsibility Initiatives Addressing Social Exclusion in Bangladesh
}

\author{
Wendy J.Werner* \\ 7 Abdullo Komandir Street, Dushanbe 73400I, Tajikistan \\ (*Former Consultant to ICDDR,B, GPO Box I28, Dhaka 1000, Bangladesh)
}

\begin{abstract}
The private sector is often seen as a driver of exclusionary processes rather than a partner in improving the health and welfare of socially-excluded populations. However, private-sector initiatives and partnershipscollectively labelled corporate social responsibility (CSR) initiatives-may be able to positively impact social status, earning potential, and access to services and resources for socially-excluded populations. This paper presents case studies of CSR projects in Bangladesh that are designed to reduce social exclusion among marginalized populations and explores whether CSR initiatives can increase economic and social capabilities to reduce exclusion. The examples provide snapshots of projects that (a) increase job-skills and employment opportunities for women, disabled women, and rehabilitated drug-users and (b) provide healthcare services to female workers and their communities. The CSR case studies cover a limited number of people but characteristics and practices replicable and scaleable across different industries, countries, and populations are identified. Common success factors from the case studies form the basis for recommendations to design and implement more CSR initiatives targeting socially-excluded groups. The analysis found that CSR has potential for positive and lasting impact on developing countries, especifically on sociallyexcluded populations. However, there is a need for additional monitoring and critical evaluation.
\end{abstract}

Key words: Corporate ethics; Corporate social responsibility; Employment; Income; Non-governmental organizations; Poverty; Rural population; Social exclusion; Bangladesh

\section{INTRODUCTION}

Improving the health and welfare of sociallyexcluded populations depends on enabling socially-excluded populations to meet their health, nutrition, and educational needs. Social change through, for instance, economic empowerment and reduced inequality has been critical in enabling sociallyexcluded populations to meet their basic human needs. In some cases, human needs can be met through various public-sector and non-governmental organizations (NGO) programmes. However, the ability of the public sector to fulfill the longterm requirements of this population segment can be limited. To achieve sustainable improvements in the health and welfare of socially-excluded populations, sustainable solutions must be found that pro-

All correspondence should be addressed to:

(Reprints are not available from the author)

Dr. Wendy J. Werner

7 Abdullo Komandir Street

Dushanbe 734001

Tajikistan

Email: wendywerner@gmail.com

Fax: +992-48-7011453 vide the populations themselves with resources and integrate these structural changes into societal institutions. As the private sector is an important and growing force in least-developed countries, the analysis considers the potential for private-sector initiatives and partnerships-collectively labelled corporate social responsibility (CSR) initiativesto impact social status, earning potential, and access to services and resources for socially-excluded populations.

CSR is an increasingly important tool to maximize the positive development impact of corporations and commercial activity in the developing world. In Bangladesh, companies, civil society organizations (CSOs)/NGOs, and development partners have adapted international practices of CSR to the local context and are working in partnership to improve employment opportunities and healthcare for excluded groups.

Interesting and significant questions remain about CSR initiatives, particularly in developing countries. The analysis presents some of these issues in the context of Bangladesh, which exhibits parallels 
with other resource-constrained developing countries. In an environment of weak enforcement of regulations, is compliance with local labour and health standards treated as CSR? Is it appropriate for a commercial entity to help provide basic community services and infrastructure? Does reliance on corporations make socially-excluded populations more vulnerable in the case of economic difficulties or shifting corporate priorities? How can NGOs, civil society, and the Government work with corporations without compromising their unique purpose and mission? The analysis of CSR case studies attempts to provide some insights into these critical questions and makes recommendations for how to design a strategy to engage the private sector in addressing the needs of socially-excluded populations while avoiding potential pitfalls.

CSR activities in Bangladesh provide specific examples of CSR implemented in developing countries from which one can draw critical lessons and recommendations for international efforts to harness the power of the private sector to achieve the Millennium Development Goals (MDGs) and improve the health and welfare of socially-excluded populations. The CSR examples included in this analysis were selected purposively to represent different strategies of the CSR-both pure private sector and partnerships of the private sector and NGOs. The paper draws from available published and grey literature and fact-checking with stakeholders.

\section{CORPORATE SOCIAL RESPONSIBILITY} AND DEVELOPMENT

CSR is an evolving concept globally but, in Bangladesh, it has been defined as a set of business practices based on ethical norms and transparency that contributes to the sustainable development of internal and external stakeholders in the best interest of business society and environment [Bangladesh Enterprise Institute. Script for CSR documentary feature (corporate). 2006 (Unpublished)]. A socially-responsible firm holds a holistic view of itself in relation to its stakeholders and measures its performance via a triple bottom-line: economic/ financial, environmental, and social. CSR seeks a path which advances all the three measures, none at the cost of the others. Although CSR as a concept may have roots in philanthropic activities, the modern view of CSR is more strategic and complex. In developing countries where basic compliance with and enforcement of national labour and environmental laws is weak, some may mischaracterize full compliance with laws and regulations as CSR. For the most part, this case study will discuss
CSR as a broader corporate strategy that goes beyond legal compliance and employee benefits.

CSR might be most relevant in developing countries where the impacts of business activities on the poor have been mixed. CSR is one method by which businesses can seek to maximize positive effects on the poor and minimize negative economic externalities (Table 1).

Strategic CSR is increasingly becoming integrated into core business operations (supplies of materials, manufacturing, provision of services, product design, marketing, etc.) (Box 1). When properly designed and implemented to fit the needs of the community and corporation, CSR can become source of opportunity, innovation, and competitive advantage (1). Strategic CSR also ensures that a business is focused on minimizing potential negative impacts of its operations. Traditional CSR (e.g. building a school or hospital) is not necessarily connected with business operations; business could have a CSR programme of education and healthcare while polluting the environment and treating workers poorly. Strategic CSR is meant to address this problem by addressing any negative value-chain impacts while supporting the business strategy and the needs of the community. For example, a company practising strategic CSR might design operations to minimize any environmental pollution, above and beyond legal requirements.

Box 1. Core business activities that can contribute to global development (2)

* Producing safe and affordable products and services

* Generating income and investment

* Creating jobs

* Developing human resources

* Building local businesses

* Spreading responsible international business standards and practices

* Supporting technology development and transfer

* Establishing physical and institutional infrastructure

Although there have been many examples in which corporations have taken advantage of developing countries and socially-excluded populations, the potential impact of corporate and business contributions to development cannot be overlooked and will likely be critical to alleviating poverty in the long term. Global trade flows and gross domestic 


\begin{tabular}{|c|c|}
\hline Positive impact & Negative impact \\
\hline Provide jobs, salaries, and benefits & Threaten livelihood \\
\hline $\begin{array}{l}\text { Even if the poor are unable to have work in the } \\
\text { formal sector, the multiplier effect of salaries can } \\
\text { boost local economies, including the informal } \\
\text { sector }\end{array}$ & $\begin{array}{l}\text { The poor may access essential goods and ser- } \\
\text { vices outside the marketplace. Their assets (water } \\
\text { rights, social networks, traditional land-use, etc.) } \\
\text { may be undermined or expropriated by the ex- } \\
\text { panding market economy }\end{array}$ \\
\hline Provide products and services & Engage in non-competitive behaviour \\
\hline $\begin{array}{l}\text { The private sector provides essential products } \\
\text { and services to all segments of society. As distri- } \\
\text { bution networks expand, poor populations may } \\
\text { have better access }\end{array}$ & $\begin{array}{l}\text { Restrictive business practices, market abuses, cor- } \\
\text { ruption, lobbying to protect vested interests, and } \\
\text { establishing monopolies or oligopolies result in } \\
\text { higher prices, fewer jobs, and barriers to the es- } \\
\text { tablishment and growth of new businesses }\end{array}$ \\
\hline Invest in research, development, and training & Impose costs on others \\
\hline $\begin{array}{l}\text { Through technology innovation, research and } \\
\text { development }(\mathrm{R} \& \mathrm{D}) \text { raises productivity levels, } \\
\text { improves products, and increases access to prod- } \\
\text { ucts and services. Business can also be a conduit } \\
\text { for new technology and business practices to de- } \\
\text { veloping countries }\end{array}$ & $\begin{array}{l}\text { Poor and rural populations often disproportion- } \\
\text { ately experience negative externalities, like pollu- } \\
\text { tion, displacement, and social upheaval }\end{array}$ \\
\hline Create private and public wealth & Exploit resources while giving li \\
\hline $\begin{array}{l}\text { Direct profits from business rarely go to the poor } \\
\text { but taxes, rents, and public service returns gener- } \\
\text { ate government revenues for public services and } \\
\text { infrastructure investment }\end{array}$ & $\begin{array}{l}\text { If businesses repatriate a majority of wealth } \\
\text { through profit repatriation, expatriate employ- } \\
\text { ment, and international sourcing, the local eco- } \\
\text { nomic multiplier is vastly reduced. Tax holidays, } \\
\text { tax avoidance, and fraudulent accounting can } \\
\text { reduce contributions to public revenues }\end{array}$ \\
\hline Trade & Create dependency relationships \\
\hline $\begin{array}{l}\text { As supply-chains become more international, } \\
\text { even companies that only operate in developed } \\
\text { countries can have a positive multiplier effect on } \\
\text { developing economies }\end{array}$ & $\begin{array}{l}\text { Particularly in resource-extraction industries, } \\
\text { business can dominate a local economy for a } \\
\text { short period without helping long-term econom- } \\
\text { ic development }\end{array}$ \\
\hline
\end{tabular}

product (GDP) dwarfs development aid budgets. If the world is to address the needs of the poorest and the socially excluded, the question is not whether business should be involved in achieving global development goals but how it should do so. The necessary approach to mobilizing the forces of business and globalization was summarized by Amartya Sen:

The point is not that the market is an evil influence, but rather that it is so alienated a process of allocation, that it can do good in fulfilling needs only to the extent that there is a congruence of needs with the ability to pay for what you want .... As an alienated institution, the market is neither hostile nor friendly, simply detached and cold. It could feed the process of a famine, but it could also assist the prevention of one. Since the market does not care which of the two it does, somebody else has to care (4).

The potential for CSR to be one of the tools to use

market forces to equalize the benefits of globalization has been recognized. Groups, such as the UN Global Compact and the International Business Leadership Forum, are working to integrate CSR activities and the global development agenda. This new and expanded role is also accepted by business. A December 2006 McKinsey Quarterly Survey of Global Business Executives found that $84 \%$ believed that large corporations should generate high returns to investors but balance that with contributions to the public good (Fig.) (5).

As companies increasingly turn to developing countries as important consumer markets, CSR becomes an important strategy to develop informed consumers, suppliers, and manufacturing networks. CSR addresses social exclusion through marketbased incentives. A larger customer base provides greater opportunities for sales and profits. A larger potential labour force ensures that companies can recruit, train, and retain high-quality employees. 
Fig. Global executives on the role of business in society (5)

Which of the following statements best describes the role that large corporations (public and private) should play in society?

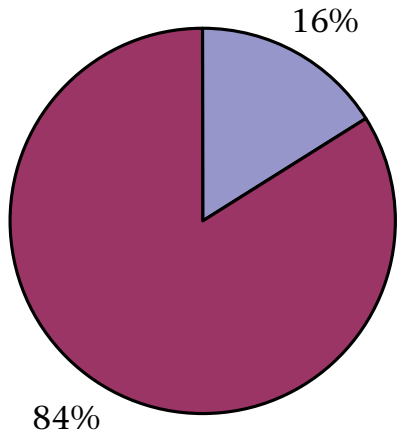

$\square$ Focus solely on providing the highest possible returns to investors while obeying all laws and regulations

$\square$ Generate high returns to investors but balance with contributions to the broader public good
Therefore, a CSR strategy that addresses sociallyexcluded groups should naturally lead to a more successful business.

Socially-excluded groups are populations that have been excluded from the advantages of economic growth and social advancement through exclusion from society based on culture, social identity, shared characteristics, etc. (6). Populations can be socially excluded based on social identities (shared values, identity, and collective action) or on the basis of shared characteristics (6). Women, rural populations, the disabled, and rehabilitated drug-users are the populations that will be discussed in relation to selected CSR programmes in this case study. A corporation is part of society and, therefore, populations that are socially excluded tend also to be excluded as employees, suppliers, and customers. In Bangladesh, women, ethnic/religious minorities, and the disabled have been traditionally excluded from mainstream commercial operations. In particular, rural populations have also been excluded from commercial operations, either because it is believed that the market potential (as consumers) is low or the area does not have sufficient labour force and infrastructure to support manufacturing or distribution activities.

\section{Traditional CSR}

Businesses can have a positive impact on health and development through three main avenues: (a) employment benefits, (b) community development and philanthropy, and (c) core business CSR strategy. The first two avenues can be broadly grouped together as traditional CSR. Traditional CSR is differentiated in motivation, implementation, and impact from Strategic CSR - the last avenue.

Traditional CSR activities that encompass health, education, and community services are usually seen as distinct and unrelated to core business op- erations. For instance, many companies provide healthcare as a benefit to employees and their families, and some even provide a community health clinic. A sample of health services provided by businesses to their employees and community is summarized in Table 2 and Box 2. Most CSR projects on health services focus on the employees, community, and stakeholders of a company. For instance, the recently-announced Grameenphone "Safe Motherhood and Infant Care" project aims at expanding community health education and outreach in hard-to-reach and coastal areas that currently are not fully covered by the health system. The project will also use its network of sales, marketing, and customer service personnel, coupled with the village phone-ladies, to provide alternative routes to disseminate health information. Grameenphone hopes that this project will assist Bangladesh in achieving the maternal and child health-related MDGs. At the launching ceremony, Grameenphone's Managing Director Erik said, "through this nationwide initiative of Safe Motherhood and Infant Care Project, Grameenphone hopes to aid in reaching these MDG targets" (7).

Some CSR initiatives target community development. Lafarge cement, for example, provides enterprise development training for women in the community surrounding its manufacturing plants to encourage small and medium-sized enterprises. Four hundred and forty-two women have been trained so far in sewing, poultry, and cattle-rearing, kitchen-gardening, candle-making, and shop management. [Babar M. Setting footprints of social responsibility. Presentation at Bangladesh Enterprise Institute. Dialogue series on CSR in action: 8th roundtable on CSR practices and challenges in Bangladesh. 2006) (Unpublished)].

Despite impressive numbers of people served by the community health projects, the numbers are 


\begin{tabular}{|c|c|c|c|}
\hline Company & Health initiatives/benefits & Population served & Partners \\
\hline $\begin{array}{l}\text { Chevron Bangla- } \\
\text { desh }\end{array}$ & $\begin{array}{l}\text { Built health clinic and provid- } \\
\text { ed } 3 \text { years' operational funds }\end{array}$ & $\begin{array}{l}44,000 \text { people served in } \\
\text { the community }\end{array}$ & $\begin{array}{l}\text { Smiling Sun health } \\
\text { clinics }\end{array}$ \\
\hline $\begin{array}{l}\text { British-American } \\
\text { Tobacco, Bangla- } \\
\text { desh (BATB) }\end{array}$ & $\begin{array}{l}\text { Health cards for BATB farm- } \\
\text { ers entitling them to receive } \\
\text { medicines and services at } \\
49 \text { satellite clinics }\end{array}$ & 2,500 farmers & $\begin{array}{l}\text { Smiling Sun health } \\
\text { clinics }\end{array}$ \\
\hline $\begin{array}{l}\text { Garment facto- } \\
\text { ries }\end{array}$ & $\begin{array}{l}\text { Basic healthcare and pre- } \\
\text { ventative care in satellite } \\
\text { clinics at factory locations } \\
\text { (Box 2) }\end{array}$ & $\begin{array}{l}\text { 110,871 workers through } \\
\text { Marie Stopes clinics } \\
12,000 \text { workers through } \\
\text { Smiling Sun clinics }\end{array}$ & $\begin{array}{l}\text { Marie Stopes Clinics } \\
\text { Society } \\
\text { Smiling Sun Clinics }\end{array}$ \\
\hline Holcim Cement & $\begin{array}{l}\text { Accident insurance for ma- } \\
\text { sons working on construc- } \\
\text { tion sites; provide insurance } \\
\text { up to Tk 50,000 (US\$ } 725 \text { ) }\end{array}$ & $\begin{array}{l}\text { 3,404 masons in } 51 \\
\text { districts }\end{array}$ & Not applicable \\
\hline $\begin{array}{l}\text { Pride Group } \\
\text { (Garments) }\end{array}$ & $\begin{array}{l}\text { On-site free medical unit } \\
\text { staffed by } 2 \text { doctors ( } 1 \\
\text { female); providing family } \\
\text { planning, routine medi- } \\
\text { cal services, and antenatal } \\
\text { check-ups; awareness pro- } \\
\text { gramme on preventative } \\
\text { healthcare and sanitation }\end{array}$ & 2,600+ employees & Not applicable \\
\hline Lafarge Cement & $\begin{array}{l}\text { Clinic and satellite clinics } \\
\text { in Chhatak, Bangladesh }\end{array}$ & $\begin{array}{l}\text { Lower child mortality } \\
\text { from } 15 \% \text { to } 8 \% \text { (2001- } \\
2005) \text { and maternal mor- } \\
\text { tality in the community } \\
\text { since clinics are in place }\end{array}$ & \\
\hline Duncan Brothers & $\begin{array}{l}\text { 50-bed hospital in tea plan- } \\
\text { tation areas }\end{array}$ & $\begin{array}{l}78,000 \text { (majority female } \\
\text { workers) residing in } \\
\text { Duncan Brothers tea } \\
\text { plantation areas }\end{array}$ & $\begin{array}{l}\text { Camellia Duncan Foun- } \\
\text { dation }\end{array}$ \\
\hline Tata (India) & $\begin{array}{l}\text { 810-bed hospital and } 11 \\
\text { dispensaries; reproductive } \\
\text { health services; community } \\
\text { health workers; HIV/AIDS- } \\
\text { prevention programme }\end{array}$ & $\begin{array}{l}1.2 \text { million patients in } \\
\text { hospital and dispensaries } \\
2 \text { million women pro- } \\
\text { vided with reproductive } \\
\text { health services } \\
98 \% \text { immunization in } \\
\text { city of Jamshedpur } \\
\text { Jamshedpur HIV preva- } \\
\text { lence rate of }<0.1 \% \text { vs } \\
4.5 \% \text { national average }\end{array}$ & $\begin{array}{l}\text { Village and community } \\
\text { committees } \\
\text { Tata Trust }\end{array}$ \\
\hline
\end{tabular}

Sources: Timmons R. NSDP and corporate social responsibility. Presentation at Bangladesh Enterprise Institute. CSR Center dialogue series on CSR in action, 2005 (Unpublished); Hussain SM. Building new perspectives in responsible business. A TATA presentation on CSR at Bangladesh Enterprise Institute. CSR Center dialogue Series on CSR in action. 2005 (Unpublished); Bangladesh Enterprise Institute. CSR and practices of selected Bangladeshi companies. 2005 [Unpublished]; Roy SK. Corporate social responsibility at Holcim. Presentation at Bangladesh Enterprise Institute. CSR Center Dialogue series on CSR in action. 2005 (Unpublished) 
small in relation to the national requirements in Bangladesh. This underscores the fact that CSR is not a replacement for public-sector services. Public services and CSR work best when coordinated; however, coordination does not imply regulation and may, therefore, involve new working methods from all partners. The market forces at work in CSR can generate consumer awareness and raise consumer demand, which, in turn, can contribute to innovation and implementation of new publicsector initiatives.

Community development and corporate healthcare can have a direct and positive impact on health outcomes for participating populations but there is a risk to the community and the company from these sorts of interventions. For example, a recent analysis of community development operations in the mining sector highlights the fact that school clinics and hospitals built as gifts to local communities have often not lasted beyond the life of the mining activities and sometimes not even past the tenure of the company's employees who drove the project. There remains a risk that without local cooperation, capacity-building, and continued community resource investment, projects in the health and education sectors are likely to collapse (8). It is this lack of embedding and sustainability that has led corporations to turn to more strategic CSR initiatives.

\section{Strategic CSR}

The case studies presented below highlight examples of strategic CSR that are integrated into core business activities to promote long-term sustainable

Box 2. Health services provided at garment factories

The ready-made garments industry is staffed mostly by women, and many of these women often suffer from chronic fatigue, skin diseases, reproductive health complaints, and respiratory problems. Some garment factories provide health services to their employees in partnership with NGOs. A network of satellite clinics has been established through a number of NGOs, including the Smiling Sun network (supported by USAID) and the Marie Stopes Clinic Society. Now that the outside provision of health services to employees is well-accepted, there is significant competition between NGOs on both price and package of health services.

Workers at 41 garment factories in Dhaka, Savar, and Chittagong are provided with health services in the workplace through the Smiling Sun programme. In all the participating factories, there are approximately 21,000 workers; the satellite clinics serve around 12,000 clients every month. Factory-owners pay a fee of Tk 3,000 to 6,000 (US\$ 43-87) per month to the clinics for providing services. Satellite clinics are operated by local NGOs. The level of cost-recovery varies among NGOs; while some are recouping 100\% of costs through fees, others are still highly subsidized. The most common complaints observed at the clinics are sexually transmitted infections (STIs), reproductive tract infections, weakness, and family planning-related complications.

Marie Stopes Clinic Society provides on-site health services at 135 factories situated in Dhaka, Tongi, Khulna, and Chittagong districts. In addition to garment factories, mobile Marie Stopes clinics are set up at fish-processing factories. Factory management pays Tk 12 (US\$ 0.17) per worker per month to provide workers with health cards that allow them to access health services from the clinic. Clinics provide general check-ups and medication, family-planning services, antenatal care, treatment for STIs, eye-tests, and immunizations. In 2006, the Marie Stopes clinics served 110,871 workers.

Business support to both initiatives is critical to their success. For Marie Stopes, fees from factory-owners cover 70\% of the costs, and factories provide space for clinics and allow workers a time-off to attend sessions. Where the Marie Stopes services have been adopted, there has been a reported marked improvement in productivity, reduced absenteeism, and an improvement in the health status of workers.

Sources: Timmons R. NSDP and corporate social responsibility. Presentation at Bangladesh Enterprise Institute. CSR Center dialogue series on CSR in action. 2005 (Unpublished); Khan M. CWFD and corporate social responsibility. Presentation at Bangladesh Enterprise Institute. CSR Center dialogue series on CSR in action. 2006 (Unpublished); Begum. Personal communication, 2007

NGOs=Non-governmental organizations; USAID=United States Agency for International Development 
incomes to excluded groups and provide the skills and experience necessary to maintain income, living standards, and health. Strategic CSR works on both direct benefits and integration of CSR practices into core business operations.

Described below are five strategic CSR initiatives in Bangladesh that target excluded groups, including women, rural populations, the disabled, and rehabilitated drug-users. In each case, excluded groups are integrated into the company's core business as customers, salespersons, and employees.

\section{Workforce and community investment by Square Group}

Square Group is a large Bangladeshi company involved in a diversified range of products and services for both domestic and export markets. The Group operates a number of manufacturing facilities in Pabna district of Bangladesh, including pharmaceuticals, toiletries, chemicals, and consumer food-products. Square's presence is strongly felt in the rural area. One in 10 households in the town include a Square employee, and including suppliers and related business activity, the employment impact of the company is overwhelming. Square Group is a model corporate citizen in Pabna, supporting community infrastructure and services and providing exemplary employment benefits to its workers. To maintain a skilled and loyal workforce, Square Group invests in rural community development and has particularly worked to make the company a women-friendly employer. Rural people in Bangladesh generally face economic and geographic exclusion based in inequality in opportunities and services. The presence of a responsible company that invests in the community means that economic and geographic exclusion in Pabna is significantly reduced.

To recruit and retain female workers, Square designs its work environment and benefits to address the needs of women. The workforce of the Square Group comprises around 26\% women. The employee turnover rate for women is very low-almost zero. Women may have a few other employment opportunities in Pabna but they can migrate to larger urban areas to expand opportunities. Given its location, Square could likely attract and retain workers even with lower standards in the workenvironment but the company goes far beyond the minimum required to attract and retain female workers; this is a good example of CSR paying dividends for the company's operations. Overall, one can conclude that the work-environment and policies of the Square Group have gained the company an extremely loyal workforce. [Bangladesh Enterprise Institute. CSR and practices of selected Bangladeshi companies. 2005) (Unpublished)]. Square employs women in all sorts of jobs, including non-traditional positions, such as petrol-pump attendant. [Bangladesh Enterprise Institute. Script for CSR documentary feature (corporate). 2006) (Unpublished)]. Merit is the basis for employment and promotion, which reduces the potential for discrimination in employment. Employment-benefits at Square Group meet and exceed local requirements and are comparable with international standards. This is notable since full compliance and the quality of benefits are extremely rare in Bangladeshi companies. Some of Square's benefits include: bonuses (five, including appropriate religious festivals); paid leave; performance bonus; profit-sharing; retirement benefits; healthcare facilities; interest-free loans; insurance programmes; education loan for dependants; and meals at factory cafeteria. [Bangladesh Enterprise Institute. CSR and practices of selected Bangladeshi companies. 2005) (Unpublished)].

In the context of Bangladesh where even the largest local companies and the public sector frequently pay salaries in arrears, the above benefits are unique and exemplary.

Particularly to meet the needs of female workers, Square provides transportation for women to and from their homes in the villages and the factories. This ensures that women can get to work in a safe environment free from harassment. Women are also provided with housing as a preferential benefit to encourage female workers. [Bangladesh Enterprise Institute. CSR and practices of selected Bangladeshi companies. 2005) (Unpublished)]. Most of these benefits go beyond legal requirements and have been designed to benefit the workforce, thereby earning their loyalty.

The CSR programmes of Square reach beyond the factory-door. The company has strategically invested in community development and improvement of public services and infrastructure. Square realized that the lack of high-quality education could become a constraint to attract and keep skilled employees in Pabna. To address this, the company has made a number of investments in education. For example, the Square Kindergarten incorporates a modern curriculum and facilities and is open to the children of employees, management, and the general community. As such, it helps break down barriers and bond the community together. The 
CSR activities of Square are meant to improve the educational opportunities in Pabna, helping to keep skilled workers in Pabna; they are also meant to improve the level of technical and communication skills among the future workforce of Square. There has been no quantitative study on the impact, which would likely take many years to manifest.

Square Group has also made an effort to improve public infrastructure that affect community health. The company has provided free medication to public hospitals and sponsored ambulances. It also made investments in the water and sanitation system, installing improved drainage systems and working to provide safe drinking-water to more population.

The CSR activities of the Square Group can be categorized as strategic initiatives that greatly benefit the community while addressing priorities for the company. Improvements in the education and sanitation systems make the district more attractive for workers and their families and for other businesses and reduce migration to urban areas. A commitment to a family-friendly work-environment and on-time provision of employee-benefits attracts skilled workers to the company.

Shoes and soap: mobile saleswomen in the CARE Rural Sales Programme

The CARE Rural Sales Programme is a partnership among Bata Shoe Company, a footwear manufacturer and retailer; Unilever, a consumer goods company; and CARE Bangladesh. The programme builds on the ability of women to earn an income from their social and village networks. The programme trains poor women in sales, financial access, and enterprise development. Training is free and, once trained, the women can buy the partner products (from Bata and Unilever). Through the programme, more than 1,000 women in nine rural districts have become mobile sales agents since April 2006.

Individual income is based on sales commissions. On an average, a saleswoman earns about Tk 500 (US\$ 7.50) monthly as sales commission. Higher sales lead to a higher income as commission. Initial success has led to the ongoing inclusion of Square Group products and more products from Unilever, which will provide opportunity for higher sales and commissions. The overall programme translates into an increase income of US\$ 90 per year for a participating woman. When compared with the Bangladesh per-capita gross national income of US\$ 470 at the time.
Work where you live: women in rural centres manufacture toys and knitwear for export

Hathay Bunano is a social business enterprise manufacturing handicrafts, toys, and knitwear for the export market. The manufacturing business strategy of Hathay Bunano uses 19 rural centres staffed by 1,800 women throughout Bangladesh. This innovative business model allows export-quality items to be produced in a rural setting. Most employees of Hathay Bunano are female. In particular, the company seeks to employ excluded populations, such as divorced, illiterate and disabled women. Hathay Bunano employs over 80 disabled workers, and many senior trainers are disabled (Morshed G and Morshed S. Personal communication, 2007). A significant number of employees are divorced and illiterate and have very young children. The poorest rural households typically involve divorced, deserted, or widowed female household heads and are characterized by low levels of education among adults (6).

In Bangladesh, the disabled face a high degree of discrimination, and this is even truer for women with disabilities (9). Many disabled women employed by Hathay Bunano are provided with housing where they work because their families are not willing to take them back after rehabilitation (Morshed, Personal Communication, 2007). Children with disabilities are often neglected; they may receive less food, clothing, and care than their siblings. This culture of discrimination has far-reaching effects; the disabled in Bangladesh frequently view themselves as inferior and only strive for survival. The disabled are likely to be relatively poor, and women are over-represented in the disabled population (9). A survey of disabled advocates and practitioners found that the perceived causes of poverty for the disabled population were: (a) lack of education; (b) lack of employment opportunities; and (c) negligence by family, relations, and the Government (10). In the context of exclusion, the disabled are socially, economically, and culturally excluded from society, and disabled women are particularly impacted on.

In this societal context, the focus of Hathay $\mathrm{Bu}$ nano on employment for disabled women and advancement based on their demonstrated abilities is a sharp contrast. Since the objective of Hathay Bunano is to alleviate poverty through employment for neglected populations, they seek out groups of women whom others would not employ or even consider. To reach and recruit disabled workers, the partners of Hathay Bunano with the Centre for Re- 
habilitation of the Paralyzed (CRP), the premier hospital and rehabilitation centre for the disabled in Bangladesh. The CRP provides therapy, rehabilitation, and vocational training to disabled men, women, and children. Hathay Bunano has integrated their production training with the vocational training at the CRP and has established two production centres staffed entirely by workers who finished the rehabilitation programme at the CRP. The partnership with the CRP enables Hathay Bunano to find good disabled workers and ensures high-quality healthcare and therapy for their disabled workers, something the company would be unable to provide independently. The occupational and physical therapy assistance from the CRP to design necessary workplace adaptations (wheel-chairs, tables, seating, etc.) ensures that disabled workers will be fully functional at work. The provision of accommodation for disabled employees is the only real adaptation that Hathay Bunano makes for them, which is required not because of any physical reason but due to the discrimination that the disabled women face (Morshed G and Morshed S. Personal communication, 2007).

Samantha Morshed, Managing Director of Hathay Bunano, says that their disabled employees are some of their best employees. Their quality of work is high as is their productivity. In fact, many trainers who establish new rural production centres are disabled; they are chosen to be trainers based on their skills and their willingness to go to another part of the country for 3-6 months at a time. The trainer is the key link between a new employee and the company. From the initial interaction with the company, employees see the disabled in positions of respect and authority (Morshed G and Morshed S. Personal communication, 2007).

The business model of Hathay Bunano is based on rural production centre. The company finds a group of at least 15-30 women in a rural area, who are interested in working and willing to undertake 1-2 month(s) of free training. NGOs and community groups are often partners in reaching the women and establishing a rural production centre. Once a group of willing women has been identified, a small production facility is established. The production centre is within a short walk of all the women's homes. A Hathay Bunano trainer who has already been working at another centre comes to train the new employees. After training for approximately 6-8 weeks in knitting, crocheting, and embroidery and following patterns, the women will be ready to start full production for export sales.
Once a production centre is in full production, the trainer chooses a supervisor from the women who have completed the training. The supervisor is chosen on the basis of merit, her demonstrated ability to learn, and product-quality, rather than any other measure of seniority or social standing. For all workers, pay and promotion are based on the quality and skill of their work. This emphasis on merit distinguishes Hathay Bunano's management structure and empowers the women in the rural production centres. The rural centre supervisor is given complete responsibility for the quality of products, functioning of the centre, payments (including a bank account in her name), and salaries of workers. All order processing, inventory, supply logistics, marketing, and design are done in headquarters. Women in the rural centres are given the responsibility to manufacture the knitted items at the required level of quality. Since Hathay Bunano's customers are high-end boutiques and retail stores in Europe and the UK, the quality of products is critical to the success of the company. This trust by the company greatly empowers women who have previously rarely worked outside the home (Morshed G and Morshed S. Personal communication, 2007).

Golam Morshed, Chairman of Hathay Bunano, reports that the rural centres often serve to build community among women in the rural areas where they are located. Due to the nature of rural society in Bangladesh, many of these women did not know one another prior to working together at the rural centre. The rural production centres are within walking distance of the women's homes and provide a safe and acceptable way for them to earn income. The piece rate salary structure also allows women to have flexibility in the amount they work and earn [Sample testing establishes the time required to make each item and the salary rate of $\mathrm{Tk}$ 10 per hour determines the piece rate for each item (e.g. an item that takes one hour to make in the sample-room will be assigned a rate of Tk 10 (US\$ 0.14 ) per piece)]; management reports that, on average, the women earn Tk 800-1,400 (US\$ 11-21) per month working part-time. Monthly salaries of Tk 2,000-4,000 (US\$28-58) could be earned working full-time. On an annual basis, women can earn US\$ 690 per year, 148\% of Bangladesh's GNI per capita. Salaries are paid on a weekly basis based on the work completed the previous week (Morshed G and Morshed S. Personal communication, 2007).

Although there are dispersed rural centres all over the country, Hathay Bunano provides a number of 
services for its employees, including childcare, a healthcare social worker, and literacy classes. They also take efforts to ensure that illiterate or low-skill women can be employed. The company continues to produce some products with very simple designs that do not make a profit to provide an opportunity to keep illiterate women employed and involved (Morshed G and Morshed S. Personal communication, 2007).

The Hathay Bunano model empowers rural, poor, illiterate, and disabled women to earn income and take on responsibility for product manufacturing. The company has a lot to teach other groups that want to use commercial activities to benefit rural and socially-excluded populations. First, the company involves socially-excluded women in the part of the value-chain where their skills are relevant and there is most opportunity for employment creation. The rural centres provide quality, employment for women through focus on one activity: production. The women are not required to participate in the other parts of the business value-chain; they do not need to know international trends, market products, source-specialized yarn, and design toys and clothes. Third, the business model and operations draw on the capabilities of women both as individual workers and as trainers and supervisors. Salaries are determined by the skill, quality, and efficiency of their work. Based on their skills, they earn consistent and significant income for their families. Finally, the rural centre model allows women to increase their earned income and skills without leaving their communities. In this way, the rural centre model anchors rural communities and discourages urban migration.

New job, new life: economic rehabilitation of injecting drug-users

Drug-users in Bangladesh are often discriminated against and have significant difficulty when returning to society after rehabilitation. Typically, more than $90 \%$ of rehabilitated drug-addicts relapse after leaving treatment. A pilot project by the JOBS project addresses this problem by providing placement for rehabilitated injecting drug-users (IDUs) in private-sector companies. The project, funded by USAID as part of a larger project on rehabilitation of drug-users, is implemented by the Family Health International (FHI). On a pilot basis, two companies have provided job placements (Takagaki E and Khan MI. Personal communication, 2007).

The target population for this project is rehabilitat- ed IDUs, many of whom are also former commercial sex workers. This target population encounters social and economic exclusion upon finishing rehabilitation of drug-users. The JOBS project aims at providing meaningful skills and employment while also creating a supportive community and enabling the target population to start a new life with more economic and social capacity, thereby reducing their social exclusion.

The first step in this project is completion of a three-month detoxification and rehabilitation by the drug-users. The FHI and JOBS have partnered with three drug-users' rehabilitation centres in Dha$\mathrm{ka}$, providing long-term residential treatment to drug-users. At the end of the treatment programme for durg-addicts, JOBS provides a course on life-skills and workplace norms, designed to teach the clients "how to be a good employee." This training includes goal-setting, planning, personal finance, expectations at workplaces, etc. After this training, clients are selected for placement in a factory-job. JOBS organizes accommodation for clients close to the factory and helps them organize all their personal items and arrangements. They are given on-the-job training before starting as full-time employees. JOBS plays an intensive support role for 3-6 months, visiting the factory and clients every week and discussing any problems or issues that may arise. The JOBS project manager discusses the performance of clients with factory supervisors and managers as well. After six months, the factory supervisors, clients, counsellors, and JOBS project manager will evaluate the best way forward for each individual. Some may choose to stay in their current employment; others may move back to their original homes. JOBS will provide start-up assistance for those who wish to start their own business and exhibit the necessary business planning and skills (Takagaki E and Khan MI. Personal communication, 2007).

In the pilot stage which started in January 2006, two factories were chosen for placement of clients in jobs. Both are large companies that had previously worked with the JOBS project and manufacture products for both domestic and export markets. One is a leather-manufacturing operation and the other is a rug manufacturer. Clients were placed in the factories in batches of 10-20, and they live together within walking distance from the factory. In the factory-jobs, clients earn Tk 1,500-1,800 (US\$ 21-26) per month) (Takagaki E and Khan MI. Personal communication, 2007).

Beyond managing accommodation, JOBS also fa- 
cilitates counsellors from the drug-users' rehabilitation centres to visit the factories each week and assists with healthcare requirements of the clients. One factory already provides healthcare to its employees which covers the JOBS clients. JOBS plans to provide further training to the factory doctor on HIV and STDs.

Preliminary results of the project to-date are positive. Among the project clients, the relapse rate back to drug-use is less than $10 \%$ compared to the normal drug-use relapse rate of $90 \%$. Most clients placed in the factories are considered to be ideal employees, exhibiting high attendance levels and excellent job performance. Some clients have already been promoted to the next higher level. The pilot project has proven both effective and efficient in the use of resources to give rehabilitated drugusers the skills and social abilities to build a new life and not relapse.

A number of key success factors can be drawn from the pilot project that are relevant to other similar projects. First, a rigorous screening and selection process involves JOBS personnel and the drug-users' rehabilitation counsellors and intensive interviews with the applicants. From the pool of potential clients who complete the three-month drug-treatment programme, the screening process identifies clients with the ability, willingness, and motivation to start a new career and a new life. Many clients are earning less income than they did in their occupations when they were using drug but there are a few complaints. This demonstrates that selected clients have the motivation and long-term mindset to take a position with lower income so as to develop opportunities and a community that will support a drug-free lifestyle in the future. That said, the selection process means that, even when the pilot project is expanded, this programme cannot include all rehabilitated drug-users.

The second success factor is the company in which clients are placed for employment. JOBS selected the companies for placement based on their good work-environment and management support for the initiative. The companies have codes of conduct and safe, high-quality factory environments. In each case, the management of the companies fully supported the initiative, and this support has translated down to the factory-floor level where no discriminatory behaviour is tolerated. Company management felt that this would be something they could do to benefit society. These two pilot companies took a risk based on an established re- lationship with the JOBS project and a strong motivation to benefit society. Their vision has been rewarded; the clients have been given the tools to stay away from drugs and earn an income, and the companies have gained high-performing, loyal employees. As such, it provides a good example of companies integrating expanded employment opportunities for socially-excluded groups into core business operations (i.e. manufacturing), which, in turn, benefits the company and society as a whole.

Third, success in preventing relapse by rehabilitated drug-users is also attributable to the fact that they are placed in a new community with a supportive living environment. The factory locations are outside Dhaka, and the employment removes the clients from family, relatives, and friends, many of whom were associated or involved with drug-use. Provision of accommodation in a group with similar experiences improves social capacity and establishes a new community. In the batch of female clients, one woman has her young child living with her in the group accommodation. Since the women work in alternating shifts, they have organized themselves to provide childcare while this mother is at the factory. The project manager also reports that some clients are planning to move their families (wives and husbands) to the factory locality and continue their employment with the factories. Rigorous selection, a high-quality workenvironment, and placement in a new, supportive community have combined to make this innovative pilot project a success. The JOBS-FHI partnership plans to scale up this project to reach more than 300 rehabilitated drug-users in the near future (Takagaki E and Khan MI. Personal communication, 2007).

\section{Bringing light to village: Rahimafrooz Solar}

The spatial dimension of exclusion tends to restrict village-based populations from services and opportunities in the formal sector. One specific example of this inequality is access to electricity. More than $70 \%$ of the population in Bangladesh is not connected to the electricity grid (11). Rahimafrooz Solar, a local company, seeks to address this inequality through installation of off-grid home solar systems in rural areas. The company works closely with NGOs, government bodies, and the World Bank to reach customers and provide electricity to villages that are off the power grid. Through the partnership, individuals can take out microcredit loans to pay for home solar systems. Rahimafrooz also provides solar systems to schools and other community facilities, which provides power to 
these institutions but also demonstrates the technology to households in the villages [Bangladesh Enterprise Institute. (Script for CSR documentary feature (corporate). 2006) (Unpublished)].

Rahimafrooz has installed more than 25,000 home solar systems and provides power to approximately 500,000 people who had little access to electricity previously [Rahimafrooz Ltd. Rahimafrooz, our company, our life. Undated (Unpublished)]. Access to power enables rural people to increase employment, household, and educational productivity. Rural electrification reduces geographic, social and economic exclusion and has a significant effect on infant and child mortality. Electrification makes water sterilization easier and improves access to health information from television and radio. Rural households with electricity have a lower probability of mortality of children aged less than five years (under-five mortality) by 0.025 (25 per 1,000) than non-electrified households (12). Home solar systems also have direct effects on indoor air quality. Solar energy replaces kerosene lamps and other biofuels and reduces carbon emissions by 350-450 kg per year in each household (13). Reduction of indoor carbon emissions can significantly impact health status; in Bangladesh, indoor air pollution is estimated to account for $8 \%$ of the total burden of disease, with higher levels of exposure for women and children aged less than five years (11).

\section{HEALTH EFFECTS OF STRATEGIC CSR}

CSR targeted at socially-excluded groups has the potential for positive impact on livelihood, household income, health, and nutrition. Social exclusion due to lack of access to economic resources has a strong effect on health outcomes. Increasing economic and social capabilities among socially-excluded groups by providing them with employment and job-skills reduces: (a) economic exclusion, (b) social exclusion, and (c) geographic/ spatial exclusion. First, increased income earned by women is likely to have a positive effect on family expenditure for food, health, and education; nutrition decision-making; and reproductive health decisions. Although no studies of CSR recipients' health outcomes are available, generally research demonstrates that increasing women's earned income has a strongly positive influence on household expenditure and health-related decisions. Second, the special support given to socially-excluded groups through participation in the CSR programmes can increase their social capital in the community. Finally, the CSR programmes can reduce geographic exclusion which reduces ruralurban migration and improves access to resources.

Chowdhury et al. found that women in Bangladesh who participated in income-generating activities increased contraceptive-use and desired smaller families (14). The effect was much more than those achieved in the national familyplanning programme. A similar positive effect of women's income and asset-holding has been measured for girl-child morbidity in Bangladesh, presumably due to better nutrition and health behaviours (The majority of illness measured in the study was respiratory illness and diarrhoea, which are influenced by household sanitation and environmental factors) (15). In-depth studies of adolescent married girls in Bangladesh has found that poverty and avoiding large dowry payments were the main reasons for early marriage. Employment opportunities among young, poor women can delay the age of marriage and first childbearing (16). Family income and expenditure data from other countries also support this point. In Taiwan, empirical research has shown that an increase in labour and non-labour income to the female household member increases family expenditure on staple food and education; the effect is significant in the case of education (17).

Anecdotal evidence also indicates a positive link between employment of socially-excluded groups and health and nutrition outcomes. Management at Hathay Bunano reports that the first change in a household after a woman earns income from her work is that chicken is added to the household diet each week. The company Chairman frequently visits rural centres and observes a marked improvement in personal hygiene, footwear, clothes, and appearance within a matter of weeks or months after women start working in the rural centres.

There is a benefit for socially-excluded groups to participate in CSR activities either as employees, distributors, suppliers, or consumers. Increasing the outreach of CSR activities to rural, poor, and previously-excluded groups provides more employment opportunities, skills development, social engagement, and sustainable incomes. Even inclusion as consumers can be positive for sociallyexcluded populations. For example, if the business strategy involves expanding distribution networks to rural areas, geographically-excluded populations will have greater access to products and services. The case study on Rahimafrooz Solar discusses the health, environmental and economic impacts of making off-grid home solar systems available (for 
purchase) in rural areas. CSR initiatives have the potential to increase economic and social capabilities that, in turn, tend to increase inclusion. In addition, strategic CSR can directly and indirectly improve the health status of the target populations.

Participation in CSR also can increase the social capital and capabilities of excluded groups. Inclusion in commercial activities will provide a strong motivation and rationale for commercial interactions and increase social standing. Lower returns on assets, investment, and education have been identified as a reason for lower consumption in socially-excluded households (6). Participation in CSR initiatives that provide support from commercial entities and partners, such as NGOs and CSOs, will provide a safety-net for continued participation in the face of challenges and ultimately help improve and increase the returns on investment in skills and education. For instance, in the case of the JOBS project with rehabilitated drug-users, the JOBS project manager and drug rehabilitation counsellors meet with factory managers on a weekly basis to identify and solve any emerging problems. Before the introduction of Hathay Bunano rural centres, the women in the community, especially the divorced, illiterate and disabled women, did not have a high social standing in the community, nor did they have their own community network. The income and respect they have gained from the Hathay Bunano work has increased their social capital markedly. In one case, a young woman who is a supervisor of a centre had been abandoned by her husband. After working with the Hathay Bunano centre for the last year, the woman has a higher standing in the community, and the couple has reconciled. Supervisors of Hathay Bunano rural centres (all women) hold all the commercial proceeds and salaries of employees in a bank account in their names whereas, before this work, many never had a bank account and would not have had the confidence to walk into the bank. Linking socially-excluded groups to businesses, civil society, NGOs, and development partners increases their social capital and improves their skills and job-abilities. Once a socially-excluded person has proven to be an efficient and productive employee, a business entity will be more likely to open opportunities to others from socially-excluded groups. A common finding was that employees and workers from the socially-excluded group were some of the best workers in the factory (Morshed G and Morshed S; Takagaki E and Khan MI. Personal communication, 2007). Hathay Bunano seeks disabled employees because they are very skilled and com- mitted to their work (Morshed G and Morshed S. Personal communication, 2007). Although socially-excluded populations may not have many other employment options, strategic CSR initiatives that are integrated into core business operations ensures a greater commitment from the business.

CSR activities can have a positive effect on sociallyexcluded groups-both directly through health services and impacts and more generally by improving economic and social capabilities of excluded populations. This positive association supports recommendations for policy measures to increase the number, scale, and scope of CSR initiatives in developing countries.

\section{CSR DESIGN TO BENEFIT SOCIALLY- EXCLUDED POPULATIONS}

The CSR programmes described here share some common characteristics and critical success factors:

- The CSR programme is part of the company's core business operations (products, manufacturing, sales, etc.)

- Partnerships with CSOs, NGOs, or donors enable corporations to concentrate on the business aspects of the project

- The CSR programme establishes a win-win for socially-excluded populations and businesses by matching skills, capabilities, and resources

These characteristics provide a guide for designing CSR initiatives to reach excluded groups.

First, the CSR initiatives are part of the core business operations of the sponsor company and, therefore, provide the potential for long-term employment and income for the socially-excluded populations. Disabled female employees of Hathay Bunano are their best, most experienced workers to train others to make the company's products. Rural sales women of CARE are expanding Unilever and Bata sales in rural areas. Rahimafrooz has just begun to tap the market for home solar systems among the villages off the grid in Bangladesh and plans to expand marketing and sales of home solar systems throughout Bangladesh. Production, marketing, and sales are the ways through which businesses make profit. By successfully linking the inclusion of excluded population to the profit-making operations of a business, one ensures that the business will not abandon these programmes in market downturns or difficult times.

Second, each of the CSR initiatives discussed here 
shares a common feature of strategic partnerships between NGOs and CSOs and business to facilitate social networks and access to information or specialized skills. For example, partnership of Hathay Bunano with the CRP ensures that the company can continue to recruit disabled women as employees. The JOBS project does not have experience in drug-users' rehabilitation programmes but the partnership with the FHI ensures that clients have received good quality, effective drug rehabilitation services. Strategic partners can be NGOs, CSOs, international organizations, religious groups, or the Government. The Government should particularly be a partner in large-scale CSR initiatives to facilitate coordination with public-health and education systems. Identifying the right strategic partner for a new CSR initiative is an important part of successful design and implementation of such an initiative. The challenges to large-scale strategic partnerships between NGOs and businesses in Bangladesh should not be underestimated as there is a significant culture of mistrust between these two sectors (18).

Third, a successful CSR initiative that benefits excluded populations and business operations must match strengths and weaknesses on both sides with skills and resources to find each side's competitive advantage. For example, Rahimafrooz needed a way to disseminate knowledge of and demonstrate the utility of its home solar systems. Village schools needed electricity and could provide a community facility, which is well-known and frequented by a majority of the village population. Schoolbased home solar systems provided electricity for students and opened up new markets for Rahimafrooz. Hathay Bunano employs women to make knitted, crocheted and embroidery products, which matches existing skills of women with product requirements of the company. Such matching of social issues and corporate priorities "moves beyond good corporate citizenship and mitigating harmful value-chain impacts to mount a small number of initiatives whose social and business benefits are large and distinctive. It is here that the opportunities for shared value truly lie" (2). This is the core of strategic CSR.

As demonstrated by the above examples, CSR can have a positive impact on excluded groups. The range of industries and methods of engagement in the cases discussed illustrates that, by applying the lessons of the past CSR programmes, CSR initiatives aimed at excluded populations are replicable and sustainable. Most initiatives are, however, in early stages, and it is, therefore, difficult to predict their long-term sustainability with full confidence. At present, even through some economic difficulties, the initiatives continue to succeed at providing opportunities to socially-excluded populations.

\section{CURRENT POLICY ACTIONS}

A number of international initiatives seek to help corporations implement high-quality CSR programmes in developing countries and contribute towards achieving the MDGs. In 2000, the UN established the Global Compact, in which the then Secretary-General Kofi Anan invited businesses to commit to working together with development agencies to advance universal social and environmental principles. Companies in the Global Compact agree to enact, as part of their business strategy, 10 principles. The principles are drawn from the UN declarations and conventions on human rights, workers' rights, anti-corruption, and the environment (Box 3). The UN Global Compact, a voluntary arrangement, encourages companies to record and publicly report their efforts to implement the principles. Twenty-nine organizations in Bangladesh are signatories to the UN Global Compact, among which a number of companies are discussed in this case study.

International compliance certification is not CSR but, in the Bangladesh context, is closely related. This certification includes social and labour issues and is becoming a strict requirement for Bangladeshi companies competing in export markets. Firms selling products in the USA and Europe increasingly require certification that includes social safeguards and audits. In the garment industry, the Worldwide Responsible Apparel Production (WRAP) Certification Program independently monitors and certifies compliance labour, workplace, customs, environmental and health and safety standards to ensure that garments are produced under lawful, humane, and ethical conditions. [WRAP is a certification used in the US apparel market]. WRAP monitors the factory for compliance with detailed practices and procedures to ensure adherence to the standards. Twenty-six garment factories in Bangladesh are WRAP-certified (19). SA8000 is another international certification system that is applied to many industries and focuses on workers' rights and conditions (20). In many cases, companies become internationally certified due to pressure from their buyers. For example, Hathay Bunano is currently preparing to become SA8000-certified so that they can take orders from large retail chains in the UK (Morshed G and Morshed S. Personal communication, 2007). 
Box 3. 10 global compact principles

Human rights

- Principle 1: Businesses should support and respect the protection of internationally-proclaimed human rights

- Principle 2: Make sure that they are not complicit in human rights abuses

Labour standards

- Principle 3: Businesses should uphold the freedom of association and the effective recognition of the right to collective bargaining

- Principle 4: Elimination of all forms of forced and compulsory labour

- Principle 5: Effective abolition of child labour

- Principle 6: Elimination of discrimination in respect of employment and occupation

Environment

- Principle 7: Businesses should support a precautionary approach to environmental challenges

- Principle 8: Undertake initiatives to promote greater environmental responsibility

- Principle 9: Encourage the development and diffusion of environment-friendly technologies Anti-corruption

- Principle 10: Businesses should work against all forms of corruption, including extortion and bribery

Source: www.unglobalcompact.org/AboutTheGC/ TheTenPrinciples/index.html

Due in part to weak regulatory systems and enforcement mechanisms, and valid variation in national labour and working standards, international compliance standards have become the driving force behind compliance efforts in developing countries. International compliance standards are higher (in some cases) than local standards and certainly higher than local common practice. Compliance efforts are not CSR but pressure for international compliance combined with a strategic CSR mindset can create a critical mass of ethical corporations that are enormously beneficial to society. Recent research indicates that compliance standards and codes of conduct are successful in improving conditions for regular workers but that more vulnerable workers (temporary, contract, migrant, etc.) are not reached by these codes, there is further scope to improve and expand the reach of these standards (21).

Just as important as undertaking, a CSR initiative is reporting to stakeholders on CSR activities and outcomes. The Global Reporting Initiative has established rigorous international standards for re- porting on sustainability issues, including social and environmental issues, aiming at making companies more accountable to stakeholders for their performance in meeting sustainable development objectives (22).

Locally, the CSR Centre at the Bangladesh Enterprise Institute, a think-tank, has been working on awareness and establishing a network of CSR practitioners. Their regular CSR in Action Dialogue series brings together multinational companies, local companies, and NGOs that work on CSR projects to discuss practical aspects to implementation. The CSR Center plans to expand its activities and services to help foster CSR in Bangladesh. Since 2006, Standard Chartered Bank and the Financial Express newspaper has also been sponsoring an annual award for CSR achievements of Bangladeshi companies.

In all, there are many useful initiatives undertaken at the national and international levels to encourage, design, and recognize high-quality CSR programmes. These initiatives have the effect of raising expectations for companies involved in CSR and providing expanded opportunities for partnerships with civil society to mobilize business behind sustainable development.

\section{POLICY RECOMMENDATIONS}

Overall, there are two major recommendations for policy action to enhance health and welfare impacts through CSR: (a) facilitate and encourage strategic CSR initiatives and (b) expand the reach and scale of CSR initiatives designed for socially-excluded populations. First, strategic CSR is integrated into the core business operations of a company and provides significant social and business benefits. Strategic CSR is most sustainable and effective. Second, all the above-discussed projects can be scaled up within Bangladesh by expanding the number of people, geographic areas, and products. Most initiatives are already in the process of replication and expansion. Many could also be replicated in other countries.

There are three main sectors that have a role to play in facilitating strategic CSR and expanded CSR initiatives for socially-excluded populations: international organizations and donors; corporations and business entities; and civil society. Recommendations for each sector are detailed below.

\section{For international organizations and donors}

To achieve the goals of improving health outcomes among socially-excluded groups, the international organizations and bilateral donor agencies could 
consider inclusion of a CSR and business engagement component in their strategies. Drawing on the examples of Bangladesh but also the international trends in CSR, possible actions include the following:

a. Facilitate independent measurement of health and social impact of strategic CSR initiatives. The lack of specific data relating to CSR initiatives is a limiting factor in proving the impact of CSR on health and expanding such programmes. Standard indicators and guidelines for monitoring and evaluation design and data collection can help businesses and civil society prove the efficacy of CSR interventions and encourage more and larger health-related CSR initiatives.

b. Facilitate more innovative partnerships similar to those exhibited in the case study examples. A critical success factor for CSR initiatives that benefit socially-excluded populations is partnerships with local, national and international organizations which can provide complimentary resources, skills, and networks to strategic CSR initiatives. Civil society organizations, including local and international NGOs, development partners, international financial institutions, governments, religious organizations, and local communities can work with businesses and corporations to design and implement CSR initiatives integrated into core business operations.

c. Scale up successful CSR initiatives through projects and partnerships. CSR may be a way to let 'market-forces' work in the social arena. Organizations can seek out innovative CSR projects that have potential for scalability and incorporate these ideas or implementation methods in future projects and partnerships.

There are two recommended methods through which the international organizations and donor agencies may wish to encourage CSR initiatives. First, consider participating more in global standards/certification efforts to include guidelines aimed at MDGs and inclusion of socially-excluded populations. WRAP, SA8000, and the Global Reporting Initiative are all examples of compliance standards/certification efforts which could expand and deepen the health standards expected from suppliers and manufacturers. For example, Institute for Development Studies at Sussex University recently recommended that codes of compliance should integrate ethical sourcing practices to improve conditions for vulnerable workers (22). A separate analysis of compliance standards should be completed to identify specific additions and prioritize which standards' setting process would benefit most from the involvement of international organizations. Second, private-sector partnerships could be incorporated into health strategies and include involvement in international initiatives, such as the Global Compact, International Business Leaders Forum, World Business Council for Sustainable Development (to name a few), and other sector-specific CSR networks, such as the Extractive Industries Transparency Initiative.

\section{For corporations and businesses}

The discussion of CSR examples in this case study illustrates the positive impact that CSR initiatives can have on socially-excluded populations. To expand this positive impact to other products, companies, and countries, corporations and business organizations can undertake the following actions to design and implement CSR initiatives:

a. Examine excluded populations that are currently part of the value- and supply-chain or have potential to become part of the value/supplychain. For example, Holcim Cement provides accident insurance for masons working in construction sites. The masons are not employees of Holcim but they are part of the value-chain that transforms the cement into a useable, valuable product $-\mathrm{a}$ building.

b. Include socially-excluded groups in stakeholder analysis. Stakeholder analysis is a tool that incorporates the viewpoints of all the various populations with an interest in a commercial operation. Stakeholders can include customers, suppliers, communities, and government. Stakeholder analysis can be used for identifying socially-excluded groups that have potential as employees, distributors, and customers.

c. Look for innovative programmes implemented by the public sector or civil society that can be scaled up and replicated. Similar to a product market, increasing the scale and scope of the project increases the opportunities for organizational efficiency and societal impact. When looking to scale up a CSR programme in a significant way, attention should be paid to coordination with the public sector, whether at the national or local level.

d. Identify win-win opportunities that match corporate priorities and weaknesses with social issues and community resources; once identified, business can be open to developing partnerships with 
CSOs that focus on human development and environmental sustainability; use partnerships to target and include socially-excluded groups.

e. When designing and implementing CSR initiatives, quantify the social objectives and monitor the results; strategic CSR initiatives should include both social and commercial goals; proving the business case for CSR through quantitative data on sales, market penetration, or customer loyalty is important to justify more CSR initiatives; strong, independently-verified data on the health and social benefits of CSR for socially-excluded and poor populations will build community support for CSR initiatives.

\section{For civil society organizations}

The final stakeholder that can create and facilitate strategic CSR initiatives is civil society. Strategic CSR initiatives provide opportunities for various community groups to leverage their social skills and networks to bring health and income benefits to socially-excluded groups. However, such partnerships may require a new outlook and mindset when designing and implementing projects. CSOs that want to participate in strategic CSR projects should consider the following recommendations:

a. Be open to creative partnerships with business but maintain independence and do not lose sight of the organization's mission and vision. Look for ethical, responsible businesses with whom the organization would be proud to be associated.

b. Provide easy entry-points for businesses to use $\mathrm{CSO} / \mathrm{NGO}$ services to benefit employees and stakeholders. The health card programmes implemented by Marie Stopes Clinic and Smiling Sun clinics in Bangladesh are good examples. Factory-owners pay a fee for health services to be provided to their employees and provided limited time and space for service provision. Many factories have participated in the programme, partly because it is quite easy to participate. Programmes like this provide businesses with a positive example of the impact from improving employee benefits and engaging in CSR. An easy entry-point may motivate some companies to expand their CSR strategy.

c. Design programmes and proposals that identify commercial and business benefits for potential corporate partners while achieving social and economic gains for target populations. Articulate the complementary nature of each party's resources and the win-win proposition offered by working together.

d. Focus on corporate partnerships for scalable projects. Smaller, limited scope projects can be best carried out by civil society alone. Projects that can be replicated and expanded to reach a large population are the best fit for a CSR partnership. Corporate resources may be able to expand the scope and scale of the project far beyond what could be accomplished otherwise. Likewise, a business interested in strategic CSR is more likely to look for a larger project with greater impact.

\section{CONCLUSION}

Strategic CSR programmes integrate core business operations with efforts to reduce the disadvantage faced by socially-excluded populations. The examples cited in the case study demonstrate that commercial activities that incorporate socially-excluded populations as employees, suppliers, distributors, and customers can contribute to capability and resource development for these populations. CSR activities can have a significantly-positive effect on socially-excluded groups-both directly through health services and impacts and more generally by improving economic and social capabilities of socially-excluded populations. This positive association supports recommendations for policy measures to increase the number, scale, and scope of CSR initiatives in developing countries.

The strategic CSR programmes described in the case study share three common characteristics. The programmes are: (a) part of the company's core business operations; (b) use partnerships with civil society or development partners; and (c) benefit both socially-excluded populations and businesses by matching skills, capabilities, and resources. These characteristics provide a guide for designing CSR initiatives to reach socially-excluded groups. The case study identifies a number of recommendations for international organizations, the corporate sector, and civil society to facilitate, design, and implement strategy of CSR initiatives.

Strategic CSR provides a unique opportunity to harness the powers of the market to benefit sociallyexcluded populations. To refer again to the words of Amartya Sen, "the market is neither hostile nor friendly, since the market does care which of the two it does, somebody has to care" (2). Strategic CSR aligns the economic motivations of "the market', in the form of businesses, with the needs of 
the poor. Bangladesh continues to be an engine of economic growth, and it is critical to harness the power of economic growth to generate social cohesion rather than perpetuate inequalities. To do otherwise is a missed opportunity and would be a grave disservice to excluded populations and the country as a whole.

\section{ACKNOWLEDGEMENTS}

This work was made possible through funding provided by the World Health Organization (WHO) to ICDDR,B and undertaken as work for the Social Exclusion Knowledge Network established as part of the WHO's Commission on the Social Determinants of Health. The views presented in this report are those of the author and do not necessarily represent the decisions, policy, or views of WHO or Commissioners.

\section{REFERENCES}

1. Porter ME, Kramer MR. Strategy and society: the link between competitive advantage and corporate social responsibility. Harv Bus Rev 2006;84:78-92, 163.

2. Nelson J, Prescott D. Business and the Millennium Development Goals: a framework for action. London: International Business Leadership Forum, 2003. $32 \mathrm{p}$.

3. Forstater M, MacDonald J, Raynard P. Business and poverty: bridging the gap. London: Prince of Wales International Business Leaders Forum, 2002. 152 p.

4. Sen A. Famine as alienation. In: Abdullah A, Khan AR, editors. State, market and development: essays in honour of Rehman Sobhan. Dhaka: Dhaka University Press Limited, 1996:15-32.

5. The McKinsey global survey of business executives: business and society. McKinsey Q 2006;(2):1-30.

6. Kabeer N. Social exclusion and the MDGs: the challenge of 'durable inequalities' in the Asian Context. The Asia 2015 Conference, London, 6-7 March 2006. 30 p. (http://www.asia2015conference.org/pdfs/Kabeer.pdf, accessed on 2 June 2007).

7. Grameenphone Ltd. Press release: Grameenphone centre opened in Sylhet. Dhaka: Information Department, Grameenphone Ltd., 2007. (http://www. grameenphone.com/index.php?id=268, accessed on 10 May 2007).

8. Vavy A. Community development toolkit: an introduction to the M\&E aspects of World Bank/ICMM's CD toolkit. London: International Council on Mining and Metals, 2005. 165 p.

9. Danish Bilharziasis Laboratory. Disability in Bangladesh: a situation analysis. Final report. Charlottenlund: Danish Bilharziasis Laboratory, 2004. 89 p.
10. Unnayan Shamannay. In quest of disability sensitive PRSP: a report based on consultations and a nationallevel round table dialogue. Dhaka: Unnayan Shamannay for Action on Disability and Development, Bangladesh, 2004. 63 p. (http://www.add.org.bd/ pdf/PRSPwork.pdf, accessed on 2, June 2007).

11. World Bank. Bangladesh country environmental analysis. Dhaka: World Bank Office, 2006. 108 p. (Bangladesh development series paper no. 12).

12. World Bank. Maintaining momentum towards the MDGs: an impact evaluation of interventions to improve maternal and child health and nutrition outcomes in Bangladesh. Washington, DC: Operations Evaluation Department, World Bank, 2005. 282 p.

13. World Bank. Energy and mining sector board, improving lives: World Bank group progress on renewable energy and energy efficiency fiscal year 2006, Washington, DC: World Bank, 2006. 27 p.

14. Chowdhury J, Amin R, Ahmed AU. Poor women's participation in income generating projects and their fertility regulation in rural Bangladesh: evidence from a recent survey. World Dev 1994:555-64.

15. Hallman KK. Mother-father resources control, marriage payments, and girl-boy health in rural Bangladesh. Washington, DC: Food Consumption and Nutrition Division, International Food Policy Research Institute, 2000. 78 p. (FCND discussion paper no. 93).

16. Rashid SF. Emerging changes in reproductive behaviour among married adolescent girls in an urban slum in Dhaka, Bangladesh. Reprod Health Matters 2006;14:151-9.

17. Thomas D, Chen C-L. Income shares and shares of income: empirical tests of models of household resource allocations. Santa Monica, CA: RAND Corporation, 1994. 37 p. (Labor and population working paper series. working paper no. 94-08).

18. Stiles K. International support for NGOs in Bangladesh: some unintended consequences. World Dev 2002;30:835-46.

19. Worldwide Responsible Apparel Production. (http:// www.wrapapparel.org/ modules.php?name=Conte $n t \& p a=$ showpage\&pid=3, 2007, accessed on 2 June 2007).

20. Social Accountability International. (www.sa-intl.org, accessed on 2 June 2007).

21. Barrientos S. Corporate codes of labour practice: can the most vulnerable workers benefit? IDS Policy Briefing 2007;35:1-4.

22. Global Reporting Initiative. (www.globalreporting. org, accessed on 2 June 2007). 